\title{
CHANGES IN GRASSLAND CHEMICAL SOIL PARAMETERS FOUR YEARS AFTER CESSATION OF DIFFERENT FERTILISATION WITH COMPOST AND SLURRY
}

\author{
Marie Štýbnarovál, Oldřich Látal ${ }^{1}$, Jan Hladký², Monika Hradilovál, Jiří \\ Skládanka², Hana Bilošová ${ }^{1}$, Martin Brtnický
}

${ }^{1}$ Agrovýzkum Rapotín Ltd.., Výzkumníků 267, 78813 Vikýřovice, Czech Republic

${ }^{2}$ Mendel university in Brno, Zemědělská 1, 61300 Brno, Czech Republic

\begin{abstract}
ŠTÝBNAROVÁ MARIE, LÁTAL OLDŘICH, HLADKÝ JAN, HRADILOVÁ MONIKA, SKLÁDANKA JIŘÍ, BILOŠOVÁ HANA, BRTNICKÝ MARTIN. 2018. Changes in Grassland Chemical Soil Parameters Four Years after Cessation of Different Fertilisation with Compost and Slurry. Acta Universitatis Agriculturae et Silviculturae Mendelianae Brunensis, 66(1): 0211-0218.

The aim of this study was to evaluate changes in chemical soil properties of permanent grasslands after the cessation of their regular utilisation and organic fertilisation. A long-term small plot trial was established in 2004 in locality Rapotín. During 2004-2012 the experiment was fertilised with compost and slurry, both with the range of stocking rates $0.9,1.4$, and 2.0 livestock units (LU).ha ${ }^{-1}$ (corresponding to 54,84 , and $120 \mathrm{~kg} \mathrm{~N} \cdot \mathrm{ha}^{-1}$ ). It was further observed the unfertilised grassland as control. The plots were cut 2-4 times per year depending on given dose of fertiliser. During 2013-2016 the regular management was ceased and the grasslands were completely abandoned. It was found statistically significant influence of the year and the type of fertiliser almost for all evaluated parameters. The dose of nitrogen was not significant. On the basis of our results we can conclude, that the both types of the organic fertilisers had a positive influence on the chemical soil properties, however, the compost manifested itself as the better fertiliser than the slurry from this point of view. In 2016, four years after the last application of the organic fertilisers, there were found the better chemical soil conditions in the treatments previously fertilised with compost.
\end{abstract}

Keywords: grassland; organic fertilisers; soil; abandonment

\section{INTRODUCTION}

For the support of the growth, the development and the proper quality of the fodder crops it is essential their adequate nutrition. In most of the enterprises that are engaged in plant and animal production it is usual to fertilise grasslands with mineral fertilisers. Therefore, many authors were aimed at the investigation of the influence of mineral fertilisation on the floristic composition of grasslands (e.g. Mrkvička and Veselá, 2002; Hejcman et al., 2007; Smits et al., 2008; Britaňák et al., 2009; Hrevušová et al., 2009; Rotar et al., 2016). The systematic utilisation of farm manures in grasslands is not common because of their preferred application in the intensive crop management on arable land. Existing methodical recommendations for the utilisation of organic fertilisers often do not take into consideration many important criterions, such as the estimation of the type and the dose of fertiliser in relation to the type of grassland, the altitude, or the date of application. Long-time experience is used in alpine regions (Buchgraber et al., 2011).

The organic fertilisers are the irreplaceable base for the rational agriculture. The high-quality farm manures support the soil fertility and have other positive effects (Samuil et al., 2009). By their correct systematic application, the important nutrients are returned back to the soil and the additional fertilisation with mineral fertilisers is not generally 
necessary in grasslands. The difference is, that the nutrients in inorganic fertilisers can be directly taken up by plants in contrast to nutrients in organic fertilisers, which have to be released by microbial metabolism to make most of them available to plants (Böhme et al., 2005).

There is an advantage of organic fertilisers which lays in the fact, that their application can positively influence the soil organic carbon content (Gonet and Debska, 2006). Microorganisms, e.g. bacteria, fungi, actinomycetes and microalgae, play a key role in organic matter decomposition, nutrient cycling and other chemical transformations in soil (Murphy et al., 2007; Chang et al., 2014). The results of Šimon and Czakó (2014) indicated that additions of organic matter from various sources differ in the effects on soil organic matter and biological activity. According these authors, long-term application of cattle slurry + straw was rather similar to mineral fertilisation. Hlisnikovský et al. (2016) came to the conclusion, that the decomposition and subsequent stabilization of fresh organic matter in time, the microbial interactions and mineralization of soil organic matter (Gude et al., 2012) and changes of contents of organic carbon were probable reasons for the subsequent decrease of easily available carbon fractions and increase of available metals in their experiment. It follows that, there should be a long-term residual effect of organic fertilisers' application (Diacono and Montemurro, 2010) which was, however, only rarely investigated in grasslands.

Another question, which has been frequently asked by scientists (e.g. Bohner et al., 2006; Prévosto et al., 2011; Pavlů et al., 2013; Ronch et al., 2013; Plesa et al., 2014), is addressed to changes after the total grassland abandonment. The abandonment of semi-natural grasslands become a major threat and raises a series of questions and situations, which have to be solved in the whole Europe (Osterburg et al., 2010). This topic is still actual, because the grassland abandonment is happening currently mainly in the less-favoured areas near the borders of the Czech Republic.

The influence of organic fertilisers (cattle slurry, in particular) has been studied e.g. Estavillo et al. (1997), Schellberg and Lock (2009), Liu et al. (2010), Lalor et al. (2011, 2012), Duffková et al. (2015), Angeringer et al. (2016). As Khalid et al. (2013) documented, compost works quite differently from mineral fertilisers, as amending soil with compost provides a slow-release source of nutrients.
Significant quantities of nutrients (particularly N, $\mathrm{P}, \mathrm{K}$ and micronutrients) became bio-available with time as compost decomposed in the soil. In addition, if sufficient heat is generated the viability of weed seeds in the material should be reduced (Younie, 2012). On the contrary, slurry is the fertiliser with a quick-release nitrogen because the ratio $\mathrm{C}: \mathrm{N}<10$ (Decree no. 474/2000 Coll.).

Our study is based on the long-term investigation of the small-plot trial with permanent grassland and it broadens the current knowledge about these topics. The aim of this work was to verify the influence of organic fertilisers on chemical properties of the soil, to compare the effects of fertilisation with slurry and compost, to assess the use of compost for fertilisation of grasslands.

\section{MATERIALS AND METHODS}

\section{Study site}

The monitoring of the influence of intensity of utilisation and type and level of grassland fertilisation with organic fertilisers was initiated in Rapotín in 2004. The experimental site was situated in the Czech Republic $\left(50^{\circ} 00432^{2} \mathrm{~N}\right.$ and $17^{\circ} 00483^{2} \mathrm{E}$ ) at $390 \mathrm{~m}$ above sea level on the east slope position (declination between 5.1 and $6.2^{\circ}$ ) in a moderately warm region without temperature extremes (Quitt, 1971). Average annual temperature is $7.2{ }^{\circ} \mathrm{C}$ and annual precipitation $693 \mathrm{~mm}$. Further meteorological data are given in Tab. I. The vegetation of the experimental area was classified as Cynosurion with some elements of Arrhenatherion (Moravec et al., 1995). Before the experiment set-up, the grassland was utilised as the pasture for cattle. The soil was sandy-loam, Haplic Cambisol with horizons Am-Bv-Bv/Cc-Cc (classification system according to IUSS Working Group WRB 2006). The chemical soil properties were determined in spring 2012 and 2016 according to the methods of Zbíral et al. (2002).

\section{Treatments}

A long-term small-plot experiment (plot size: $12.5 \mathrm{~m}^{2}$ ) in completely randomised blocks with four replicates was investigated on permanent grassland. Two types of organic fertilisers were applied during 2004-2012: (S) cattle slurry, and (C) compost. Organic fertilisers were used in annual doses of nitrogen: $54 \mathrm{~kg} \cdot \mathrm{ha}^{-1}, 84 \mathrm{~kg} \cdot \mathrm{ha}^{-1}$ and

I: Long-term annual average [1961-1990] in temperatures and precipitations in the locality of Rapotín

\begin{tabular}{lc}
\hline & Normal \\
\hline Average temperature during the vegetation season $\left[{ }^{\circ} \mathbf{C}\right]$ & 9.1 \\
Average annual temperature $\left[{ }^{\circ} \mathbf{C}\right]$ & 7.2 \\
Average precipitation during the vegetation season $[\mathrm{mm}]$ & 481 \\
Average annual precipitation $[\mathrm{mm}]$ & 693 \\
\hline
\end{tabular}


$120 \mathrm{~kg} \cdot \mathrm{ha}^{-1}$, which approximately corresponded to $0.9 \mathrm{LU}^{-h^{-1}}$ (LU = livestock unit), 1.4 LU.ha ${ }^{-1}$ and 2.0 LU.ha ${ }^{-1}$. The fertilisers were analysed for the content of nutrients before their application, which was conducted annually during 2004-2012. Average concentration of nitrogen in organic fertilisers was $3.6 \%$ (in dry matter) for slurry and $1.3 \%$ (in dry matter) for compost. Average concentrations of other elements in the organic fertilisers are mentioned in Tab. II. The first half of the doses of the cattle slurry (diluted with water in a ratio 1:3) as well as the compost was applied early in spring and the second one after the first cut. The plots were cut two to four times per year depending on the given dose of fertiliser. Treatments of the fertilisation and the cutting regime are given in Tab. III.

During 2013-2016, the regular management was ceased and the grasslands were completely abandoned for this time.

\section{Evaluated parameters}

The soil chemical properties were evaluated in two laboratories. The accredited laboratory of Agrovyzkum Rapotin Ltd. determined $1)$ the content of total organic carbon $\left(\mathrm{C}_{\mathrm{ox}}\right)$ using spectrophotometry according to Zbíral et al. (2004), 2) the content of basic macronutrients ( $\mathrm{Mg}, \mathrm{Ca}, \mathrm{P}$, K) in the Mehlich-3 Extractant (Mehlich, 1984), 3) the exchangeable soil reaction ( $\mathrm{pH} 1 \mathrm{M} \mathrm{CaCl}_{2}$ ), and 4 ) the content of total Kjeldahl nitrogen $\left(\mathrm{N}_{\text {tot }}\right)$ by means of the Kjeldahl method.

The laboratory of Research Institute for Soil and Water Conservation (In Czech VÚMOP, v.v.i.) determined the fractional composition of humus substances: HA - humic acids and FA - fulvic acids by means of the method of short fractionation according to Konová and Bělčíková (1963).

\section{Statistical analyses}

Analysis of variance (ANOVA) followed by Tukey HSD test $(P<0.05)$, and further the T-test $(P<0.05)$, were used for the statistical data analysis by means of the software Statistica v. 10.

\section{RESULTS AND DISCUSSION}

Chemical parameters of soil determined in spring 2011 and 2016 are shown in Tab. IV.

Tab. V shows the statistically significant differences in particular characteristics between years 2011 and 2016.

Concerning the exchangeable soil reaction, it was found statistically significant $(P<0.05)$ influence of the year and of the type of fertiliser. The factor "dose of nitrogen" was not significant. From Tab. IV it is obvious, that in 2016 , the $\mathrm{pH}$ value was significantly higher than in 2011 (5.20 and 4.92, respectively). Further, it was found, that the fertilisation with compost increased the soil reaction. On average,

II: Average concentrations of elements in organic fertilisers (in dry matter)

\begin{tabular}{|c|c|c|c|c|c|c|c|c|c|}
\hline \multirow{2}{*}{ Fertiliser } & $\mathbf{P}$ & $\mathbf{K}$ & $\mathrm{Ca}$ & $\mathrm{Mg}$ & Cd & Zn & Co & $\mathbf{C u}$ & $\mathrm{C}^{*}$ \\
\hline & \multicolumn{8}{|c|}{$\left(\mathrm{mg} \cdot \mathrm{kg}^{-1}\right)$} & $(\%)$ \\
\hline Slurry & 6,611 & 26,284 & 11,770 & 24,928 & 0.142 & 329 & 4.2 & 29 & 35 \\
\hline Compost & 4,239 & 22,331 & 20,584 & 76,274 & 0.012 & 273 & 3.9 & 35 & 52 \\
\hline
\end{tabular}

*C - total content of carbon determined by loss ignition method

III: Description of treatments with different grassland management (before abandonment)

\begin{tabular}{|c|c|c|c|c|c|c|c|}
\hline Treatment & Fertilisation & $\begin{array}{l}\text { Annual dose } \\
\text { of nitrogen }\end{array}$ & Application & $1^{\text {st }}$ cut & $2^{\text {nd }}$ cut & $3^{\text {rd }}$ cut & $4^{\text {th }}$ cut \\
\hline S-0.9 & $\begin{array}{c}\text { cattle slurry } \\
\text { (diluted with } \\
\text { water } 1: 3 \text { ) }\end{array}$ & 54 kg.ha-1 & $\begin{array}{c}50 \% \text { of dose - in spring, } \\
50 \% \text { of dose - after the } 1^{\text {st }} \text { cut }\end{array}$ & June 15 & Sept. 30 & - & - \\
\hline S-1.4 & $\begin{array}{c}\text { cattle slurry } \\
\text { (diluted with } \\
\text { water } 1: 3 \text { ) }\end{array}$ & $84 \mathrm{~kg} \cdot \mathrm{ha}^{-1}$ & $\begin{array}{l}50 \% \text { of dose - in spring, } \\
50 \% \text { of dose - after the } 1^{\text {st }} \text { cut }\end{array}$ & May 30 & July 30 & Sept. 30 & - \\
\hline S-2.0 & $\begin{array}{c}\text { cattle slurry } \\
\text { (diluted with } \\
\text { water } 1: 3 \text { ) }\end{array}$ & $120 \mathrm{~kg} \cdot \mathrm{ha}^{-1}$ & $\begin{array}{l}50 \% \text { of dose - in spring, } \\
50 \% \text { of dose - after the } 1^{\text {st }} \text { cut }\end{array}$ & May 15 & June 30 & Aug. 15 & Sept. 15 \\
\hline C-0.9 & compost & 54 kg.ha- ${ }^{-1}$ & $\begin{array}{l}50 \% \text { of dose - in spring, } \\
50 \% \text { of dose - after the } 1^{\text {st }} \text { cut }\end{array}$ & June 15 & Sept. 30 & - & - \\
\hline C-1.4 & compost & 84 kg.ha-1 & $\begin{array}{l}50 \% \text { of dose - in spring, } \\
50 \% \text { of dose - after the } 1^{\text {st }} \text { cut }\end{array}$ & May 30 & July 30 & Sept. 30 & - \\
\hline C-2.0 & compost & $120 \mathrm{~kg} \cdot \mathrm{ha}^{-1}$ & $\begin{array}{c}50 \% \text { of dose - in spring, } \\
50 \% \text { of dose - after the } 1^{\text {st }} \text { cut }\end{array}$ & May 15 & June 30 & Aug. 15 & Sept. 15 \\
\hline
\end{tabular}


the highest $\mathrm{pH}$ value showed the compost treatments (5.25) compared to the slurry treatments (4.97) and the controls without fertilisation (4.78). The long-term organic fertilisers application can lead to the decrease of soil reaction as mentioned e.g. Meng et al. (2005) or Bastida et al. (2008), however the compost has got the puffer ability and it can soften the soil acidity (Florián, 2014), as it was proved also by our results. Higher $\mathrm{pH}$ is important in view of reality that under acidic, waterlogged conditions, high organic matter can further increase potential toxicity (Carrow et al., 2001).

Further, it was found statistically significant influence of the year and of the type of fertiliser for the content of $\mathrm{N}_{\text {tot }}$. In 2016, the content of $\mathrm{N}_{\text {tot }}$ was significantly higher than in $2011(0.21 \%$ and $0.19 \%$ respectively). On average, the highest content of $\mathrm{N}_{\text {tot }}$ showed the compost treatments $(0.21 \%)$ compared to the slurry treatments $(0.19 \%)$ and the controls without fertilisation (0.17\%). Many authors referred, that any type of organic fertiliser increased

IV: Chemical parameters of soil determined in spring 2011 and 2016

\begin{tabular}{|c|c|c|c|c|c|c|c|c|c|c|c|c|}
\hline \multirow[b]{2}{*}{ Year } & \multirow[b]{2}{*}{ Treatment } & \multirow{2}{*}{$\frac{\mathrm{pH}}{\left(\mathrm{CaCl}_{2}\right)}$} & \multirow{2}{*}{$\frac{\mathrm{C}_{\mathrm{ox}}}{(\%)}$} & \multirow{2}{*}{$\frac{\mathbf{N}_{\text {tot }}}{(\%)}$} & \multirow{2}{*}{$\frac{\text { Ratio }}{\mathbf{C} / \mathbf{N}}$} & \multirow{2}{*}{$\frac{\text { HA }}{(\%)}$} & \multirow{2}{*}{$\frac{\text { FA }}{(\%)}$} & \multirow{2}{*}{$\begin{array}{c}\text { Ratio } \\
\text { HA/FA }\end{array}$} & \multirow{2}{*}{$\frac{P}{(\mathrm{mg} .}$} & \multirow{2}{*}{$\frac{\mathrm{K}}{(\mathrm{mg} .}$} & \multirow{2}{*}{$\frac{\mathrm{Ca}}{(\mathrm{mg} .}$} & \multirow{2}{*}{$\begin{array}{c}\mathrm{Mg} \\
(\mathrm{mg} . \\
\left.\mathrm{kg}^{-1}\right)\end{array}$} \\
\hline & & & & & & & & & & & & \\
\hline 2011 & Control & 4.75 & 1.46 & 0.18 & 8.08 & 0.26 & 0.46 & 0.58 & 53 & 159 & 1,944 & 173 \\
\hline 2011 & S-0.9 & 4.83 & 1.59 & 0.19 & 8.53 & 0.30 & 0.36 & 0.84 & 59 & 161 & 2,078 & 209 \\
\hline 2011 & S-1.4 & 4.70 & 1.44 & 0.17 & 8.51 & 0.26 & 0.35 & 0.74 & 55 & 155 & 1,954 & 185 \\
\hline 2011 & S-2.0 & 4.78 & 1.41 & 0.17 & 8.16 & 0.28 & 0.45 & 0.62 & 48 & 162 & 1,855 & 195 \\
\hline 2011 & C-0.9 & 5.13 & 1.58 & 0.20 & 8.11 & 0.34 & 0.45 & 0.75 & 74 & 196 & 2,399 & 228 \\
\hline 2011 & C-1.4 & 5.07 & 1.61 & 0.19 & 8.43 & 0.34 & 0.43 & 0.80 & 70 & 151 & 2,383 & 216 \\
\hline 2011 & C-2.0 & 5.21 & 1.74 & 0.20 & 8.56 & 0.34 & 0.50 & 0.68 & 92 & 180 & 2,493 & 260 \\
\hline 2016 & Control & 4.81 & 0.70 & 0.16 & 4.40 & 0.24 & 0.37 & 0.66 & 50 & 142 & 1,660 & 197 \\
\hline 2016 & S-0.9 & 5.16 & 0.88 & 0.20 & 4.33 & 0.32 & 0.39 & 0.80 & 46 & 150 & 2,118 & 269 \\
\hline 2016 & S-1.4 & 5.18 & 0.85 & 0.20 & 4.21 & 0.33 & 0.38 & 0.85 & 61 & 124 & 2,125 & 291 \\
\hline 2016 & S-2.0 & 5.17 & 0.93 & 0.19 & 4.86 & 0.30 & 0.38 & 0.79 & 57 & 107 & 2,107 & 296 \\
\hline 2016 & C-0.9 & 5.43 & 1.20 & 0.24 & 5.05 & 0.49 & 0.42 & 1.16 & 75 & 138 & 1,760 & 279 \\
\hline 2016 & C-1.4 & 5.12 & 1.13 & 0.22 & 5.15 & 0.40 & 0.39 & 1.02 & 64 & 114 & 2,823 & 321 \\
\hline 2016 & C-2.0 & 5.52 & 1.17 & 0.22 & 5.19 & 0.48 & 0.41 & 1.16 & 93 & 127 & 2,742 & 323 \\
\hline \multicolumn{13}{|c|}{ Means - Year } \\
\hline 2011 & & $4.92^{a}$ & $1.55^{\mathrm{a}}$ & $0.19^{a}$ & $8.34^{a}$ & $0.30^{\mathrm{a}}$ & $0.43^{\mathrm{a}}$ & $0.72^{a}$ & 65 & $166^{\mathrm{a}}$ & 2,158 & $209^{a}$ \\
\hline 2016 & & $5.20^{\mathrm{b}}$ & $0.98^{\mathrm{b}}$ & $0.21^{\mathrm{b}}$ & $4.74^{\mathrm{b}}$ & $0.36^{\mathrm{b}}$ & $0.39^{b}$ & $0.92^{\mathrm{b}}$ & 64 & $129^{b}$ & 2,191 & $282^{\mathrm{b}}$ \\
\hline \multicolumn{13}{|c|}{ Means - Fertiliser } \\
\hline Nil-fer & ilisation & $4.78^{a}$ & $1.08^{\mathrm{a}}$ & $0.17^{\mathrm{a}}$ & $6.24^{\mathrm{a}}$ & $0.25^{\mathrm{a}}$ & $0.41^{\mathrm{ab}}$ & $0.62^{\mathrm{a}}$ & $51^{a}$ & 150 & $1,802^{a}$ & $185^{\mathrm{a}}$ \\
\hline Slurry & & $4.97^{a}$ & $1.18^{\mathrm{a}}$ & $0.19^{\mathrm{b}}$ & $6.43^{\mathrm{ab}}$ & $0.30^{\mathrm{a}}$ & $0.39^{a}$ & $0.77^{\mathrm{b}}$ & $54^{\mathrm{a}}$ & 143 & $2,039^{a}$ & $241^{\mathrm{b}}$ \\
\hline Compo & & $5.25^{\mathrm{b}}$ & $1.41^{\mathrm{b}}$ & $0.21^{\mathrm{c}}$ & $6.75^{\mathrm{b}}$ & $0.40^{\mathrm{b}}$ & $0.43^{\mathrm{b}}$ & $0.93^{c}$ & $78^{b}$ & 151 & $2,433^{b}$ & $271^{\mathrm{c}}$ \\
\hline \multicolumn{13}{|c|}{$\begin{array}{l}\text { Means - Dose of } \\
\text { nitrogen }\end{array}$} \\
\hline $0 \mathrm{~kg} \cdot \mathrm{ha}$ & & 4.78 & 1.08 & 0.17 & 6.24 & 0.25 & $0.41^{\mathrm{ab}}$ & 0.62 & 51 & 150 & 1,802 & $185^{a}$ \\
\hline $54 \mathrm{~kg} . \mathrm{h}$ & & 5.14 & 1.31 & 0.21 & 6.50 & 0.36 & $0.40^{\mathrm{ab}}$ & 0.89 & 63 & 161 & 2,089 & $246^{\mathrm{b}}$ \\
\hline $84 \mathrm{~kg} . \mathrm{h}$ & & 5.02 & 1.26 & 0.20 & 6.57 & 0.33 & $0.39^{a}$ & 0.85 & 62 & 136 & 2,321 & $253^{b}$ \\
\hline $120 \mathrm{~kg}$. & $\mathrm{ha}^{-1}$ & 5.17 & 1.31 & 0.20 & 6.69 & 0.35 & $0.43^{b}$ & 0.81 & 73 & 144 & 2,299 & $268^{b}$ \\
\hline Factor & & & & & & & $P$-value & & & & & \\
\hline Year & & $<0.001$ & $<0.001$ & $<0.001$ & $<0.001$ & $<0.001$ & 0.001 & $<0.001$ & 0.843 & $<0.001$ & 0.752 & $<0.001$ \\
\hline Fertilis & & $<0.001$ & $<0.001$ & $<0.001$ & 0.029 & $<0.001$ & $<0.001$ & $<0.001$ & $<0.001$ & 0.333 & 0.001 & $<0.001$ \\
\hline Dose of & nitrogen & 0.214 & 0.401 & 0.230 & 0.545 & 0.380 & 0.006 & 0.287 & 0.245 & 0.054 & 0.179 & 0.048 \\
\hline
\end{tabular}

Legend: $\mathrm{S}=$ slurry; $\mathrm{C}=$ compost; $0.9 ; 1.4 ; 2.0=$ model stocking rate $\left(\mathrm{LU}_{\mathrm{H}}\right.$.ha ${ }^{-1}$;

$\mathrm{C}_{\mathrm{ox}}=$ total organic carbon; $\mathrm{N}_{\text {tot }}=$ total Kjeldahl nitrogen; $\mathrm{HA}=$ humic acids; $\mathrm{FA}=$ fulvic acids

(Soil quality parameters were determined according to the methods of Zbíral et al. 2002.)

The values in the same column with different superscript letters are significantly different at $P<0.05$ level for each variable (Tukey's HSD test). 
V: T-test results between years 2011 and 2016

\begin{tabular}{cccccccccccc}
\hline & $\mathbf{p H}$ & $\mathbf{C}_{\text {ox }}$ & $\mathbf{N}_{\text {tot }}$ & $\mathbf{C} / \mathbf{N}$ & $\mathbf{H A}$ & $\mathbf{F A}$ & $\mathbf{H A} / \mathbf{F A}$ & $\mathbf{P}$ & $\mathbf{K}$ & $\mathbf{C a}$ & $\mathbf{M g}$ \\
\hline $\mathbf{2 0 1 1}$ & 0.008692 & 0.227240 & 0.077296 & 0.905861 & 0.036986 & 0.016741 & 0.811673 & 0.124035 & 0.280041 & 0.038000 & 0.102346 \\
$\mathbf{2 0 1 6}$ & 0.274034 & 0.007132 & 0.029316 & 0.064497 & 0.048785 & 0.092827 & 0.044450 & 0.152554 & 0.978939 & 0.441710 & 0.069472 \\
\hline
\end{tabular}

the content of $\mathrm{N}_{\text {tot }}$ in the soil (Blackshaw et al., 2005; Leroy et al., 2007). In our case, there was found the statistically significant difference $(P<0.05)$ in the content of $\mathrm{N}_{\text {tot }}$ in the treatments fertilised with compost and slurry, whereas the content of $\mathrm{N}_{\text {tot }}$ was significantly higher in the compost treatments. This finding is in agreement with Whalen and Chang (2002), who mentioned that compost is better organic fertiliser, because the important nutrients are available in the soil in a higher amount and in a longer period. According to Younie (2012) converts much of the $\mathrm{N}$ to more stable forms of organic $\mathrm{N}$ which are less susceptible to loss during and after application in the field. However, considerable volatilization losses of $\mathrm{N}$ will occur during the composting process itself. Further, Diacono and Montemurro (2010) mentioned, that repeated long-term applications of organic amendments not only generally increase the size of the soil organic $\mathrm{N}$ pool, but also cause remarkable changes in soil characteristics, that influence $\mathrm{N}$ dynamics and can lead to a residual effect. Habteselassie et al. (2006) found an $89 \%$ increase in total soil $\mathrm{N}$ content after 5 years when dairy-waste compost at $200 \mathrm{~kg} \mathrm{ha}^{-1}$ $\mathrm{N}$ was applied. The increase in total soil $\mathrm{N}$ content was found also in our study four years after the last fertilisers' application, which was the most apparent in the treatments fertilised with compost.

As for the content of $\mathrm{C}_{\mathrm{ox}}$, (which represents the primary soil organic matter), also in this case it was found statistically significant $(P<0.05)$ influence of the year and of the type of fertiliser. In 2016 , the content of $C_{\text {ox }}$ was significantly lower than in $2011(0.98 \%$ and $1.55 \%$, respectively). On average, the highest content of $\mathrm{C}_{\text {ox }}$ showed the compost treatments $(1.41 \%)$ compared to the slurry treatments $(1.18 \%)$ and the controls without fertilisation (1.08\%). Montemurro et al. (2006) documented, that the compost is the better source of the organic matter, which is more stable in a long-term. It was observed also in our study.

Within our study, we evaluated the humus quality, whereas the basic indicator of the quality of humus is the ratio $\mathrm{C} / \mathrm{N}$. Generally, the narrower value than 10 means the better humus quality and vice versa (Fiala and Krhovjáková, 2009). We have found, that the value of this ration was below 10 in all treatments, however, in 2016, the ratio $\mathrm{C} / \mathrm{N}$ was significantly narrower than in 2011 (4.74 and 8.34, respectively). On average, the compost treatments (6.75) differed significantly $(P<0.05)$ from the controls (6.24).

The humus quality was further estimated by means of the contents of humic acids and fulvic acids. The wider ratio HA/FA means the dominance of humic acids and the higher humus quality and vice versa (Bensa et al., 2015). It means also the higher degree of humification. The values of ratio HA/FA between 0.5-1.0 means the degree of humification between $20-30 \%$. The values of ratio HA/FA between 1.0-2.0 means the degree of humification between 30-40\%. We have found statistically significant $(P<0.05)$ influence of the year and of the type of fertiliser, whereas in 2016, the ratio HA/FA was significantly wider than in 2011. On average, the compost treatments (0.93) differed significantly $(P<0.05)$ from the slurry treatments $(0.77)$ and from the controls without fertilisation (0.62). The widest ratio HA/FA was found in the compost treatments in 2016, whereas the ratio exceeded the value 1 for all treatment of doses of nitrogen.

Finally, we evaluated the differences between treatments in the content of basic macronutrients. From Tab. IV it is apparent, that there were found differences within treatments and years and some of them were significant $(P<0.05)$. It was found statistically significant difference $(P<0.05)$ between the years 2011 and 2016 in the content of $\mathrm{K}$ and $\mathrm{Mg}$. Significant difference between the types of fertiliser was found for all macronutrients (except potassium), whereas the highest content of macronutrients showed the compost treatments. Concerning the potassium, it was found also the significant influence of the year, whereas the higher content of $\mathrm{K}$ was found in 2011 (166 mg. $\mathrm{kg}^{-1}$ ) compared to 2016 (129 mg. $\mathrm{kg}^{-1}$ ). The most significant differences were found for the magnesium, whereas the significant was the factor "type of the fertiliser" as well as its „dose”. As it is apparent in Tab. IV, the highest content of $\mathrm{Mg}$ was found for the highest dose of compost in 2016 (323 mg. $\mathrm{kg}^{-1}$ ); the lowest was found in the control treatment in 2011 (173 mg.kg-1). Diacono and Montemuro (2010) documented that the organic fertilisation increases the amount of available nutrients, which finding was demonstrated also in our study. Nevertheless, as it is apparent from Tab. IV, mainly the compost application increased the supply of soil with the available nutrients.

These findings are in line with the results of Šimon and Czakó (2014), who referred that additions of organic matter from various sources, can differ in the effects on soil organic matter and biological activity. Generally, the composts are slowly decomposed in the soil, the continuous release of nutrients can sustain the microbial biomass population for longer periods of time (Murphy et al., 2007).

Application of the organic matter into the soil has also the positive influence on the utilisation of nutrients by the plants (Watson et al., 2002). Organic fertiliser is according to the authors 
Montemurro et al. (2004) the important source of organic matter, nitrogen and other nutrients. In addition, the organic fertilisation has also ecological and economical importance, because the cycle of nutrients is closed. Our study showed, that the compost application lead to the stabilization of the organic matter, and subsequently there were positively influenced the chemical soil properties, which is in line with Moral et al. (2009). Another important advantage of compost lays in the fact, that the use of compost reduces nitrogen (nitrate) losses from the soil as emphasized Plošek et al. (2017), which, however, was not the subject of this paper.
Equally important is the fact, that the compost contained less potassium and more magnesium than slurry. After application of $\mathrm{K}$ fertiliser, potassium supply in soil solution will be temporally plentiful and in this situation the plants take up more $\mathrm{K}$ than need for optimum growth. Luxury uptake of $\mathrm{K}$ can cause metabolic disorders such as magnesium or sodium deficiency. Miller and Miller (2000) emphasized that the application of organic matter into the soil has not the immediate effect and the improvement of the soil characteristics can be expected in a long-term scale.

\section{CONCLUSION}

On the basis of our results we can conclude, that the both types of the organic fertilisers had a positive influence on the chemical soil properties, however, the compost was the better fertiliser than the slurry from this point of view. In 2016, four years after the last application of the organic fertilisers, there were found the better chemical soil conditions in the treatments previously fertilised with the compost. Thus, the application of compost lead to the improvement of the chemical soil properties even four years after cessation of the fertilisation. Furthermore, the use of compost reduces nitrogen losses and leads to increased soil $\mathrm{pH}$.

\section{Acknowledgements}

This work was supported by the institutional support for the long-term conceptual development of the research organisation, Ministry of Agriculture Decision No. RO1217 from 23 February 2017 and by the project of the Ministry of Education, Youth and Sports No. LG15025.

\section{REFERENCES}

ANGERINGER, W., KARRER, G., STARZ, W., PFISTER, R. and ROHRER, H. 2016. Short-term effects of cutting frequency and organic fertiliser on species composition in semi-natural meadows. Grassland Science in Europe, 21: 705-707.

BASTIDA, F., KANDELER, E., HERNÁNDEZ, T. and GARCÍA, C. 2008. Long-term Effect of Municipal Solid Waste Amendment on Microbial Abundance and Humus-associated Enzyme Activities Under Semiarid Conditions. Microbial Ecology, 55(4): 651-661.

BENSA, A., BOSKO, M. and ZDRAVKA, S. Š. 2015. Humus quality in hydromorphic soils of the island of Rab. Agriculturae Conspectus Scientificus, 80(1): 47-51.

BLACKSHAW, R. E., MOLNAR, L. J. and LARNEY, F. J. 2005. Fertiliser, manure and compost effects on weed growth and competition with winter wheat in western Canada. Crop Protection, 24(11): 971-980.

BÖHME, L., LANGER, U. and BÖHME, F. 2005. Microbial biomass, enzyme activities and microbial community structure in two European long-term experiments. Agriculture, Ecosystems and Environment, 109: 141-152.

BOHNER, A., ÖHLINGER, R. and TOMANOVA, O. 2006. Effects of grassland management and abandonment on vegetation, soil, microbial biomass and forage quality. Bodenkultur, 57(1):33-45.

BRITAŇÁK, N., ILAVSKÁ, I. and HANZES, L. 2009. An impact of mineral fertilisation on the stability of seminatural grassland at excessive or deficient rainfall. Agriculture (Polnohospodárstvo), 55(3): 139-146.

BUCHGRABER, K., SCHAUMBERGER, A. and PÖTSCH, E. 2011. Grassland farming in Austria - status quo and future prospective. Grassland Science in Europe, 16: 12-24.

CARROW, R. N., WADDINGTON, D. V. and RIEKE, P. E. 2001. Turfgrass Soil Fertility and Chemical Problems: Assessment and Management. John Wiley \& Sons, Inc.

CHANG, E.H., WANG, C.H., CHEN, C.L. and CHUNG, R.S. 2014. Effects of long-term treatments of different organic fertilisers complemented with chemical $\mathrm{N}$ fertiliser on the chemical and biological properties of soils. Soil Science and Plant Nutrition, 60(4): 499-511.

DIACONO, M. and MONTEMURRO, F. 2010. Long-term effects of organic amendments on soil fertility. A review. Agronomy for Sustainable Development, 30(2): 401-422.

DUFFKOVÁ, R., HEJCMAN, M. and LIBICHOVÁ, H. 2015. Effect of cattle slurry on soil and herbage chemical properties, yield, nutrient balance and plant species composition of moderately dry Arrhenatherion grassland. Agriculture, Ecosystems and Environment, 213: 281-289. 
ESTAVILLO, J. M., RODRÍ, M., LACUESTA, M. and GONZALES-MURUA, C. 1997. Effects of cattle slurry and mineral $\mathrm{N}$ fertiliser applications on various components of the $\mathrm{N}$ balance of mown grassland. Plant and Soil, 188(1): 49-58.

FIALA, K. and KRHOVJÁKOVÁ, J. 2009. Metodické postupy a zásady vyhodnocování chemických parametrů puid pod trualými travními porosty. Agrovýzkum Rapotín Ltd.

FLORIÁN, M. 2014. Agronomickézkoušenízemédẻlských pưd a význam vápnèní. [Online]. Available at: http://www. zeraagency.eu/dokumenty/008009001/florian_miroslav_ukzuz_brno.pdf [Accessed: 2017, July 5].

GONET, S. S. and DEBSKA, B. 2006. Dissolved organic carbon and dissolved nitrogen in soil under different fertilisation treatments. Plant, Soil and Environment, 52(2): 55-63.

GUDE, A., KANDELER, E. and GLEIXNER, G. 2012. Input related microbial carbon dynamic of soil organic matter in particle size fractions. Soil Biology and Biochemistry, 47: 209-219.

HABTESELASSIE, M. Y., MILLER, B. E., THACKER, S. G., STARK, J. M. and NORTON, J. M. 2006. Soil nitrogen and nutrient dynamics after repeated application of treated dairy-waste. Soil Science Society of America Journal, 70(4): 1328-1337.

HEJCMAN, M., KLAUDISOVÁ, M., SCHELLBERG, J. and HONSOVÁ, D. 2007. The Rengen Grassland Experiment: Plant species composition after 64 years of fertiliser application. Agriculture, Ecosystems and Environment, 122: 259-266.

HLISNIKOVSKÝ, L., MÜHLBACHOVÁ, G., KUNZOVÁ, E., HEJCMAN, M. and PECHOVÁ, M. 2016. Changes of risky element concentrations under organic and mineral fertilisation. Plant, Soil and Environment, 62(8):355-360.

HREVUŠOVÁ, Z., HEJCMAN, M., PAVLŮ, V., HAKL, J., KLAUDISOVÁ, M. and MRKVIČKA, J. 2009. Long-term dynamics of biomass production, soil chemical properties and plant species composition of alluvial grassland after the cessation of fertiliser application in the Czech Republic. Agriculture, Ecosystems and Environment, 130(3-4): 123-130.

IUSS WORKING GROUP WRB. 2006. World reference base for soil resources 2006. World Soil Resources Reports, No. 103. Rome: FAO.

KHALID, A., MOURAD, M., ALAMI, I. T., LAHCEN, K. and BRAHIM, S. 2013. Effect of slow release organic nitrogen fertiliser combined with compost on soil fertility, yield and quality of organic zucchini in sandy soil. In: Paper of the 15th RAMIRAN International Conference. Versailles France.

KONOVÁ, M. M. and BĚLČÍKOVÁ, N. P. 1963. Uskorennyj metod opredelenija sostava gumusa mineralnych počv. In: Organičeskoje vešestvo počvy, Moskva.pp. 228-234.

LALOR, S. T. J., HOEKSTRA, N. J., MURPHY, P. N. C., RICHARDS, K. G. and LANIGAN, G. J. 2012. Practical advice for slurry application strategies for grassland systems. International Fertiliser Society.

LALOR, S. T. J., SCHRÖDER, J. J., LANTINGA, E. A., OENEMA, O., KIRWAN, L. and SCHULTE, R. P. O. 2011. Nitrogen fertiliser replacement value of cattle slurry in grassland as affected by method and timing of application. Journal of Environment Quality, 40(2): 362-373.

LEROY, B. L. M. M., BOMMELE, L., REHEUL, D., MOENS, M. and DE NEVE, S. 2007. The application of vegetable, fruit and garden waste (VFG) compost in addition to cattle slurry in a silage maize monoculture: Effects on soil fauna and yield. European Journal of Soil Biology, 43(2): 91-100.

LIU, W., ZHU, Y. G., CHRISTIE, P. and LAIDLAW, A. S. 2010. Botanical composition, production and nutrient status of an originally Lolium perenne-dominant cut grass sward receiving long-term manure applications. Plant and Soil, 326(1-2):355-367.

MEHLICH, A. 1984. Mehlich 3 soil test extractant: A modification of Mehlich-2 extractant. Commun. Soil Sci. Plant Anal., 15(12): 1409-1416.

MENG, L., DING, W. and CAI, Z. 2005. Long-term application of organic manure and nitrogen fertiliser on N2O emissions, soil quality and crop production in a sandy loam soil. Soil Biology and Biochemistry, 37(11): 2037-2045.

MILLER, D. M. and MILLER, W. P. 2000. Land application of wastes. In: SUMNER, M. (Ed). Handbook of soil science. CRC Press. Chap. 9.

MONTEMURRO, F., CONVERTINI, G. and FERRI, D. 2004. Mill wastewater and olive pomace compost as amendments for rye-grass. Agronomie, 24(8): 481-486.

MONTEMURRO,F., MAIORANA, M., CONVERTINI, G. andFERRI,D. 2006. CompostOrganic Amendments in Fodder Crops: Effects on Yield, Nitrogen Utilization and Soil Characteristics. Compost Science, 14(2): 114123.

MORAL, R., PAREDES, C., BUSTAMANTE, M. A., MARHUENDA-EGEA F. and BERNAL, M. P. 2009. Utilisation of manure composts by high-value crops: Safety and environmental challenges. Bioresource Technology, 100(22): 5454-5460.

MORAVEC, J., BALÁTOVÁ-TULÁČKOVÁ, E., BLAŽKOVÁ, D. et al. 1995. Rostlinná společenstva České republiky a jejich ohrožení [In Czech: Red list of plant communities of the Czech Republic and their endangerment]. 2nd Edition. Litoměřice.

MRKVIČKA, J. and VESELÁ, M. 2002. The influence of long-term fertilisation on species diversity and yield potential of permanent meadow stand. Rostlinná Výroba, 48(2): 69-75. 
MURPHY, D. V., STOCKDALE, E. A., BROOKES, P. C. and GOULDING, K. W. T. 2007. Impact of microorganisms on chemical transformation in soil. In: Soil biological fertility - A key to sustainable land use in agriculture. Springer. pp. 37-59.

OSTERBURG, B., ISERMEYER, F., LASSEN, B. and RÖDER, N. 2010. Impact of economic and political drivers on grassland use in the EU. Grassland Science in Europe, 15: 14-28.

PAVLUீ, L., PAVLUீ, V., HEJCMAN, M. and GAISLER, J. 2013. What is the effect of long-term cutting versus abandonment on the vegetation and chemical properties in the soil and the herbage of a mountain hay meadow (Polygono-Trisetion)? In: Revitalising Grassland to Sustain our Communities: Proceedings of the $22^{\text {nd }}$ International Grassland Congress, Sept 15-19, Sydney. pp. 1675-1696.

PLESA, A., ROTAR, I., PĂCURAR, F. and VIDICAN, R. 2014. The semi-natural grasslands in different successional stages of abandonment. Lucrări Științifice, Universitatea de Stiinte Agricole Și Medicină Veterinară „Ion Ionescu de la Brad“ Iași, Seria Agronomie, 57(1): 105-109.

PLOŠEK, L., ELBL, J., LOŠÁK, T., KUŽEL, S., KINTL, A., JUŘIČKA, D., KYNICKÝ, J., MARTENSSON, A., BRTNICKÝ, M. 2017. Leaching of mineral nitrogen in the soil influenced by addition of compost and N-mineral fertilizer. Acta Agriculturae Scandinavica, Section B: Soil and Plant Science, article in press.

PRÉVOSTO, B., KUITERS, L., BERNHARDT-RÖMERMANN, M., DÖLLE, M., SCHMIDT, W., HOFFMANN, M., VAN UYTVANCK, J., BOHNER, A., KREINER, D., STADLER, J., KLOTZ, S. and BRANDL, R. 2011. Impacts of land abandonment on vegetation: successional pathways in European habitats. Folia Geobotanica, 46:303-325.

QUITT, E. 1971. Klimatickéoblasti Československa [In Czech: Climatic regions of Czechoslovakia]. Brno: Geografický ústav ČSAV.

DA RONCH, F., PORNARO, C., MACOLINO, S. and ZILIOTTO, U. 2013. Effects of abandonment on some characteristics of mountain pastures. Grassland Science in Europe, 18: 457-459.

ROTAR, I., PĂCURAR, F., BALÁZSI, Á. and VIDICAN, R. 2016. The effects of mulching and mineral fertilisers on oligotrophic grasslands' floristic composition. Grassland Science in Europe, 21: 681-683.

SAMUIL, C., VINTU, V., IACOB, T., SAGHIN, G. H. and TROFIN, A. 2009. Management of permanent grasslands in North-Eastern Romania. Grassland Science in Europe, 14: 234-237.

SCHELLBERG, J. and LOCK, R. 2009. A site-specific slurry application technique on grassland and on arable crops. Bioresource Technology, 100(1): 280-286.

SMITS, N. A. C., WILLEMS, J. H. and BOBBINK, R. 2008. Long-term after-effects of fertilisation on the restoration of calcareous grasslands. Applied Vegetation Science, 11(2): 279-286.

ŠIMON, T. and CZAKÓ, A. 2014. Influence of long-term application of organic and inorganic fertilisers on soil properties. Plant, Soil and Environment, 60(7): 314-319.

WATSON, C. A., ATKINSON, D., GOSLING, P., JACKSON, L. R. and RAYNS, F. W. 2002. Managing soil fertility in organic farming systems. Soil Use and Management, 18(1): 239-247.

WHALEN, J. K. and CHANG, C. 2002. Macroaggregate Characteristics in Cultivated Soils after 25 Annual Manure Applications. Soil Science Society of America Journal, 66(5): 1637-1647.

YOUNIE, D. 2012. Grassland Management for Organic Farmers. The Crowood Press.

ZBÍRAL, J. (Ed). 2002. Analýza pi̊d I. Jednotnépracovní postupy. Brno: ÚKZÚZ, Brno.

ZBÍRAL, J. (Ed). 2004. Analýza puid III. Jednotnépracovní postupy. Brno: ÚKZÚZ, Brno. 